STUDIA Z PRAWA WYZNANIOWEGO

Tom $24-2021$

DOI: https://doi.org/10.31743/spw.12667

TOMASZ SZYSZLAK*

\title{
WPŁYW SEKURYTYZACJI UKRAIŃSKIEGO KOŚCIOŁA PRAWOSŁAWNEGO W JEDNOŚCI Z PATRIARCHATEM MOSKIEWSKIM NA ZMIANY W USTAWODAWSTWIE WYZNANIOWYM UKRAINY PO 2013 R.
}

The impact of securitization of the Ukrainian Orthodox Church (Moscow Patriarchate) on the changes in Ukrainian law on religion after 2013

Streszczenie: W artykule przedstawiono wpływ procesu sekurytyzacji Ukraińskiego Kościoła Prawosławnego w jedności z Patriarchatem Moskiewskim na zmiany w ustawodawstwie wyznaniowym Ukrainy od rewolucji godności (Euromajdanu). Wyodrębniana na gruncie nauk o bezpieczeństwie sekurytyzacja należy do podejść konstruktywistycznych, ponieważ zgodnie z tym ujęciem zagrożenie nie jest zjawiskiem realnym. Zagrożenie jest subiektywnie wskazywane przez aktora procesu oraz za takie uznawane przez jego odbiorców. Na gruncie pracy sam proces sekurytyzacji nie jest przedmiotem zainteresowania. Podkreślono okoliczności towarzyszące jego skutkom w zakresie regulacji wyznaniowych, wśród których zidentyfikowano wojnę w Donbasie i przyznanie autokefalii Kościołowi Prawosławnemu Ukrainy przez Patriarchat Ekumeniczny. Omówione zostały akty normatywne przyjęte po 2013 r., zobowiązujące Ukraiński Kościół Prawosławny do uwzględnienia w swojej nazwie podporządkowania Rosyjskiemu Kościołowi Prawosławnemu, ułatwiające wspólnotom parafialnym zmianę podporządkowania jurysdykcyjnego, a także utrudniające funkcjonowanie duszpasterstwa wojskowego w Siłach Zbrojnych i innych formacjach wojskowych.

Słowa kluczowe: sekurytyzacja; Ukraina; Ukraiński Kościół Prawosławny; Patriarchat Moskiewski; Euromajdan

* Dr, Zakład Badań Wschodnich, Instytut Studiów Międzynarodowych, Uniwersytet Wrocławski, ul. Koszarowa 3 bud. 21, 51-149 Wrocław, e-mail: tomasz.szyszlak@uwr.edu.pl. ORCID: 0000-0002-0281-3377. 
Abstract: The article presents the impact of the process of securitization of the Ukrainian Orthodox Church (Moscow Patriarchate) on the changes in Ukrainian law on religion since the Revolution of Dignity (Euromaidan). Securitization as a concept originated in security sciences belongs to constructivist approaches because under these approaches the threat is not a real phenomenon. The threat is subjectively indicated by the actor of the process and recognized as such by its recipients. Although this study is not concerned with the securitization process itself, it emphasizes the circumstances surrounding its consequences for law on religion. Among these circumstances is the war in Donbas and granting autocephaly to the Ukrainian Orthodox Church by the Ecumenical Patriarchate. The article discusses the normative acts adopted after 2013, which oblige the Ukrainian Orthodox Church to include its subordination to the Russian Orthodox Church in its name, making it easier for parish communities to change their jurisdictional subordination and hindering the functioning of military pastoral care in the Armed Forces and other military formations.

Key words: securitization; Ukraine; Ukrainian Orthodox Church; Moscow Patriarchate; Euromaidan

\section{WPROWADZENIE}

Pojęcie sekurytyzacji używane jest dość powszechnie przez zwolenników podejścia konstruktywistycznego w naukach o bezpieczeństwie, na gruncie których oznacza ,,proces [...], w którym podmiot określa pewną kwestię lub inny podmiot jako «zagrożenie egzystencjalne» dla niego, a określenie to zostaje przyjęte przez odbiorców". W ramach procesu sekurytyzacji zagrożony podmiot dąży do zastosowania ekstraordynaryjnych środków w imię zapewnienia bezpieczeństwa. Elementami procesu sekurytyzacji są: 1) dostrzegający obiektywne zagrożenia dla żywotnych wartości aktor; 2) obiekt odniesienia (bezpieczeństwa), który musi być chroniony przed zagrożeniem; 3) akt mowy, za pomocą jakiego społeczność zostaje przekonana, że dany problem stanowi zagrożenie dla bezpieczeństwa ${ }^{1}$. Rozumienie sekurytyzacji jest zatem odmienne niż na gruncie nauk prawnych, gdzie oznacza rodzaj operacji finansowej polegającej na zamianie wierzytelności na papiery wartościowe (akcje lub obligacje) dłużnika.

1 Fijałkowski 2012, 149-162; Wróblewski 2017, 62-63. 
Sekurytyzowane są również kościoły i inne związki wyznaniowe, przede wszystkim te o charakterze mniejszościowym² ${ }^{2}$, nietradycyjnym dla danej społeczności, sekty i nowe ruchy religijne, ale czasem zdarza się, że sekurytyzowana jest cała sfera sakralna. Tak było ze stosunkiem do religii w epoce Kultu Rozumu doby rewolucji francuskiej czy Związku Wojujących Bezbożników w rządzonym przez Józefa Stalina Związku Radzieckim. Niemniej rzadziej mamy do czynienia z sytuacją, kiedy sekurytyzowane są jedynie największe wspólnoty konfesyjne, jak w przypadku analizowanym w niniejszym artykule. W takim razie sekurytyzacji podlegają hierarchowie i duchowieństwo, głoszone przez nich idee o charakterze pozareligijnym (russkij mir), nie zaś doktryna religijna. Według L. Hofreitera, ,sekurytyzacja religii i tożsamości religijnej jest istotnym problemem głównie wtedy, gdy nie odróżnia religii od pewnego rodzaju ideologii wykorzystującej niektóre wartości religijne według własnych potrzeb i celów”3.

Jak zauważa A. Kozyrska, w ukraińskich pracach naukowych i publicystyce bardzo często łączy się zagadnienie istnienia niezależnego kościoła prawosławnego z kwestią bezpieczeństwa narodowego. W tym kontekście zwraca się uwagę na aspekt wewnętrzny zagrożeń (brak jedności pomiędzy ukraińskimi wspólnotami prawosławnymi oraz konflikty międzywyznaniowe), ale również aspekt zewnętrzny (administracyjne podporządkowanie ukraińskich organizacji religijnych ośrodkom zagranicznym lub bliskie kontakty z nimi, a także pośrednia zależność od polityki obcych państw), zwłaszcza w kontekście zależności Ukraińskiego Kościoła Prawosławnego (UKP) od Patriarchatu Moskiewskiego ${ }^{4}$. Aktualnie krytykowany jest także negatywny stosunek UKP do idei budowy państwa narodowego, pozytywny do prorosyjskiego separatyzmu na wschodzie kraju oraz współpracy z określonymi ugrupowaniami politycznymi i politykami. Szeregi hierarchów i duchowieństwa tegoż Kościoła penetrowane są przez rosyjskie służby specjalne, co na przestrzeni ostatnich lat co najmniej kilkukrotnie udowodniono 5 .

2 Na zasadzie analogii z wprowadzonym przez E. Szyszlak terminem ,sekurytyzacja mniejszości narodowych i etnicznych”. Por. Szyszlak 2015.

3 Hofreiter 2012, 83-84.

4 Kozyrska 2014, 363.

5 Генерал ЗСУ розповів про участь УПЦ МП у війні на Донбасі, https://24tv.ua/ general_zsu_rozpoviv_pro_uchast_upts_mp_u_viyni_na_donbasi_n913141 [dostęp: 24.01.2021]; 
Kiedy zakończyła się u naszego południowo-wschodniego sąsiada rewolucja godności (nazywana też Euromajdanem), Federacja Rosyjska anektowała Autonomiczną Republikę Krym, a we wschodnich częściach obwodów donieckiego i ługańskiego powstały prorosyjskie quasi-państwa, rozpoczął się proces sekurytyzacji Patriarchatu Moskiewskiego i jego lokalnych struktur kościelnych. Celem niniejszego artykułu jest przyjrzenie się efektom procesu sekurytyzacji w kontekście zmian w ukraińskim ustawodawstwie wyznaniowym dokonanych przez władze, które znajdowały się u sterów rządów w kraju w latach 2014-2019. Naczelna hipoteza sprowadza się do stwierdzenia, że przyjęte w okresie dominacji na scenie politycznej Petra Poroszenki oraz jego ugrupowania politycznego w Radzie Najwyższej VIII kadencji doszło do wprowadzenia lub prób wprowadzenia do ukraińskiego systemu prawnego rozwiązań jawnie dyskryminujących znajdujący się w jurysdykcji Patriarchatu Moskiewskiego UKP. To właśnie ówczesne ośrodki władzy (prezydent, rząd, parlament) zidentyfikujemy jako aktora procesu sekurytyzacji, zaś Ukrainę jako obiekt odniesienia.

2. STATUS PRAWNY UKRAIŃSKIEGO KOŚCIOŁA PRAWOSŁAWNEGO (PATRIARCHATU MOSKIEWSKIEGO) PRZED REWOLUCJĄ GODNOŚCI

Ukraiński Kościół Prawosławny powstał formalnie na mocy decyzji Synodu Rosyjskiego Kościoła Prawosławnego (RKP) z dnia 27 października 1990 r., przekształcającej funkcjonujący od 1921 r. egzarchat ukraiński w samorządową strukturę o szerokiej autonomii w jurysdykcji Patriarchatu Moskiewskiego. Na czele Kościoła stanął Filaret (Denysenko), dotychczasowy egzarcha, który przyjął tytuł metropolity kijowskiego i całej Ukrainy. Zmiana nie wywarła żadnego wpływu na strukturę religijną Ukrainy, gdyż UKP był następcą prawnym egzarchatu i jako taki był jedyną wspólnotą prawosławną uznaną przez władze.

С. Соколов, СБУ відкрила справу проти кліриків УПЦ МП через дискримінацію, https:// www.dw.com/uk/cбу-відкрила-справу-проти-кліриків-упц-мп-через-дискримінацію [dostęp: 24.01.2021]. 
Niemniej przełom lat 80. i 90. XX w. to okres eksplozji życia religijnego na Ukrainie. Obok wspólnot do tej pory funkcjonujących pojawiają się takie, które nie miały prawa działać w czasach realnego socjalizmu, w tym Ukraiński Autokefaliczny Kościół Prawosławny (UAKP) czy też Ukraiński Kościół Grekokatolicki (UKG). W tym burzliwym okresie 23 kwietnia 1991 r. uchwalono ustawę o wolności sumienia i organizacjach religijnych, w zdecydowany sposób liberalizującą przepisy radzieckiego prawa wyznaniowego, przyjęte na przestrzeni ostatnich ponad siedmiu dekad, która w swym zasadniczym zrębie obowiązuje do dzisiaj'

Ogromnym obciążeniem dla UKP była secesja dość sporej części hierarchów (na czele z metropolitą Filaretem), duchowieństwa i wiernych, którzy w 1992 r. połączyli się ze strukturami UAKP, tworząc największą opozycję wobec UKP, czyli Ukraiński Kościół Prawosławny-Patriarchat Kijowski (UKP PK). Powstanie nowej konfesji było zgodne z ówczesną racją stanu, gdyż - jak zauważa cytowana już A. Kozyrska - ,rządzący państwem obawiali się niekorzystnego wpływu, który mógł wywierać na miliony obywateli ukraińskich moskiewski ośrodek duchowy, nieprzychylny sprawie ukraińskiej. Zależność kościelną Ukrainy traktowano nawet jako zagrożenie dla młodej państwowości ukraińskiej”". Po roku w nowej wspólnocie doszło do konfliktu i większość osób wcześniej identyfikujących się z UAKP odeszła kontynuując swoją działalność pod szyldem autokefalii. Wraz z przegraną prezydenta Leonida Krawczuka w walce o reelekcję w $1994 \mathrm{r}$. idea niezależności ukraińskiego prawosławia straciła protektorat, który na krótko przywróciły rządy Wiktora Juszczenki i w końcu prezydentura Petro Poroszenki. Po wielu próbach połączenia obediencji prawosławnych pod koniec 2018 r. odbył się w Kijowie sobór zjednoczeniowy, na którym niekanoniczne struktury kościelne weszły w skład Kościoła Prawosławnego Ukrainy, uznanego przez Patriarchat Konstantynopolitański ${ }^{8}$, ale nie przez Patriarchat Moskiewski i większość światowej ortodoksji.

6 Закон Украӥни № 988-ХII „Про свободу совісті та релігійні організації”, „Відомості Верховної Ради” 1991, № 25, ст. 283. Ustawa w polskiej wersji językowej ukazała się w mojej książce: Szyszlak 2012, 317-328. Omówienie ustawy na tle rozwiązań innych państw byłego ZSRR zob. Szyszlak 2007.

Kozyrska 2014, 321.

8 Szerzej na ten temat zob. Szyszlak 2020. 
W odniesieniu do UKP przed 2014 r. można stwierdzić, że o ile ustawodawstwo wyznaniowe zachowywało całkowitą neutralność, to w praktyce politycznej można zauważyć pewne elementy procesu sekurytyzacji. Zauważam to $\mathrm{w}$ kontekście chociażby przekazywania na rzecz wspólnot religijnych nieruchomości sakralnych, które zostały znacjonalizowane w okresie komunizmu i do tej pory należały do państwa. Władze obawiały się, że przekazanie choćby stołecznego Soboru Mądrości Bożej czy całego kompleksu Ławry Peczerskiej na rzecz UKP zaburzy budowany z pietyzmem mit o neutralności światopoglądowej państwa. Stąd też dominującym rozwiązaniem było przyjęcie formuły dzierżawy, jak w przypadku Bliskich i Dalekich Pieczar, które tymczasowo, do czasu wybudowania katedralnego Soboru Zmartwychwstania Pańskiego, stanowią siedzibę zwierzchnika UKP.

Niemniej w okresie prezydentury Wiktora Janukowycza doszło do zaburzenia modelu relacji państwowo-kościelnych, kształtowanego na przestrzeni ponad dwóch ostatnich dekad, nie w kierunku sekurytyzacji jakiejkolwiek denominacji, ale podkreślania znaczenia UKP na tle innych wspólnot. Jak wspomina M. Strutyński, uważano, że głowa państwa łamie zasadę współpracy ze wszystkimi konfesjami, a dowodem na to miało być m.in. niezaproszenie na inaugurację prezydentury przedstawicieli innych niż UKP denominacji wchodzących w skład Ogólnoukraińskiej Rady Kościołów i Organizacji Religijnych ${ }^{9}$. Ta ostatnia struktura powstała jeszcze w połowie lat 90. XX w. z inicjatywy prezydenta Leonida Kuczmy jako forum współpracy największych wspólnot religijnych na Ukrainie i partner w rozmowach z najwyższymi organami władzy państwowej.

\section{SEKURYTYZACJA UKRAIŃSKIEGO KOŚCIOŁA PRAWOSŁAWNEGO (PATRIARCHATU MOSKIEWSKIEGO) OD REWOLUCJI GODNOŚCI}

Jeszcze podczas wydarzeń rewolucji godności, trwającej od listopada 2013 r. do lutego 2014 r. dało się zauważyć negatywny stosunek ze strony UKP do protestujących i wysuwanych przez nich postulatów. W wyróżnianym w procesie sekurytyzacji akcie mowy przedstawiciele ówczesnej

9 Strutyński 2014, 260-261. 
opozycji, którzy po ucieczce W. Janukowycza i utracie rządów przez Partię Regionów przejęli władzę, zaczęły wybrzmiewać argumenty, że UKP jest narzędziem w rękach Kremla i tak naprawdę jest wspólnotą, z którą identyfikuje się mniejszość Ukraińców. Co się tyczy pierwszego z nich, to podkreślano formalne podporządkowanie UKP Patriarchatowi Moskiewskiemu i swoisty dalszy ciąg cezaropapizmu połączonego z systemem supremacji, czyli totalnego jurysdykcjonalizmu, według nomenklatury H. Misztala ${ }^{10}$. Kulminacja tego typu retoryki przypadła na 2018 r. i 2019 r., co związane było z kampaniami wyborczymi, prezydencką i parlamentarną. Ubiegający się o reelekcję P. Poroszenko przyjął sobie za punkt honoru uzyskanie dla ukraińskiego prawosławia statusu autokefalii, a mottem swojej kampanii uczynił hasło „Armia, język, wiara”, wskazujące na trzy fundamenty ukraińskiej polityki.

Co do drugiego zarzutu, to w ukraińskiej rzeczywistości dość poważnym problemem jest określenie wielkości wspólnot konfesyjnych. $\mathrm{Z}$ jednej strony dysponujemy państwowymi danymi z zakresu statystyki religijnej, gromadzonymi przez ukraińskie Ministerstwo Kultury, z drugiej badaniami socjologicznymi, które często nie pokrywają się ze sobą. O ile nie ulega wątpliwości, że UKP posiada największą liczbę parafii, diecezji, klasztorów, to odmiennie wygląda sprawa z deklaracjami przynależności konfesyjnej Ukraińców. Zgodnie z ostatnimi opublikowanymi danymi państwowymi 1 stycznia 2019 r. UKP był w posiadaniu 12347 parafii oraz 337 innych podmiotów (diecezje, klasztory, misje, bractwa, szkoły), co stanowiło ponad 1/3 wszystkich parafii różnych wyznań (35 162) oraz ponad $1 / 5$ innych podmiotów (1577) tychże wspólnot w skali kraju. Dla porównania, drugi pod względem struktury organizacyjnej kościół UKP PK posiadał w tym czasie 5363 parafie i 152 inne podmioty, natomiast wszystkie denominacje protestanckie - 10031 parafii i 564 innych podmiotów ${ }^{11}$. W kontekście tematu artykułu warto zwrócić uwagę na zmianę liczby parafii UKP i UKP PK w latach 2014-2019: o ile w 2014 r. UKP posiadał 12714 parafii, to jego największy oponent 4667. Nastąpił zatem

10 Misztal 2003, 48.

11 Релігійні організаиії в Україні (станом на 1 січня 2019 р.), https://risu.ua/religiyni -organizaciji-v-ukrajini-stanom-na-1-sichnya-2019-r_n97463 [dostęp: 24.01.2021]. 
spadek stanu posiadania UKP o 367 parafii (tj. o blisko 3\%) i wzrost w przypadku UKP PK o 696 parafii (tj. o blisko 15\%) (2. $^{12}$.

W opozycji do powyższych statystyk należy przytoczyć wyniki badań socjologicznych, prowadzonych konsekwentnie od 2000 r. przez Ukraińskie Centrum Badań Ekonomicznych i Politycznych im. Ołeksandra Razumkowa. Ostatnia edycja została przeprowadzona w dniach 1-8 października 2020 r. na reprezentatywnej grupie 2020 dorosłych respondentów ze wszystkich regionów Ukrainy, poza Krymem i tymczasowo okupowanymi rejonami Donbasu. Zgodnie z nimi 67,9\% Ukraińców uważa się za osoby wierzące (w 2014 r. - 76\%), a spośród nich 62,3\% zadeklarowało przywiązanie do prawosławia (w 2014 r. - 70\%). Spośród wszystkich interlokutorów 20\% zadeklarowało przynależność do Kościoła Prawosławnego Ukrainy (32,2\% osób deklarujących się jako prawosławne), natomiast 13,6\% do UKP (21,9\% osób deklarujących się jako prawosławne). Co interesujące, większość osób określających się jako prawosławne deklaruje brak przynależności jurysdykcyjnej ${ }^{13}$. Wysunięcie się na czoło rankingu niekanonicznych wspólnot prawosławnych datuje się od $2014 \mathrm{r}$.

W połowie kwietnia 2018 r. niezależnie od siebie Rada Najwyższa i prezydent Petro Poroszenko zwrócili się do patriarchy ekumenicznego Bartłomieja I (Archondonisa) z prośbą o przyznanie kościołowi na Ukrainie autokefalii, którą poparły UKP PK oraz UAKP. W odpowiedzi stambulski hierarcha stwierdził, że Konstantynopol nigdy nie zgodził się na przekazanie terytorium Ukrainy komukolwiek, z wyjątkiem prawa chirotonii metropolitów kijowskich w Moskwie, pod warunkiem jego wyboru w Kijowie przez miejscowy sobór oraz bezwzględnego poinformowania patriarchy ekumenicznego, tym samym inkorporowanie metropolii kijowskiej do RKP pozbawione było podstaw kanonicznych. Jesienią taki punkt widzenia podzielił Święty Synod Patriarchatu Ekumenicznego, zaznaczając, że Ukraina stanowi terytorium kanoniczne podległe

12 Релігійні організації в Украӥні (станом на 1 січня 2014 p.), https://risu.ua/religiyni-organizaciji-v-ukrajini-stanom-na-1-sichnya-2014-r_n68068 [dostęp: 24.01.2021].

13 Особливості релігійного $і$ иерковно-релігійного самовизначення громадян України: тендениіі 2000-2020рр. Інформаційні матеріали підготовлені до чергового засідання постійно діючого Круглого столу „Релігія $і$ влада в Украӥні: проблеми взаємовідносин” 25 листопада 2020 р. за сприяння Представнищтва Фонду Конрада Аденауера в Україні, Київ 2020. 
bezpośrednio Konstantynopolowi i jako takie w najbliższej przyszłości otrzyma autokefalię. W dniu 15 grudnia 2018 r. odbył się w kijowskim Soborze Sofijskim sobór zjednoczeniowy, na którym zgromadzeni, przede wszystkim reprezentanci UKP PK i UAKP, zdecydowali o samorozwiązaniu i erygowaniu Kościoła Prawosławnego Ukrainy (KPU). Nowej wspólnocie Patriarchat Ekumeniczny nadał autokefalię na mocy tomosu podpisanego dnia 6 stycznia 2019 r. na stambulskim Fanarze.

\section{KWESTIA NAZWY UKRAIŃSKIEGO KOŚCIOŁA PRAWOSŁAWNEGO (PATRIARCHATU MOSKIEWSKIEGO)}

Kilka dni po soborze zjednoczeniowym, na posiedzeniu 20 grudnia 2018 r. ukraiński parlament przyjął ustawę nowelizującą przepisy prawne w zakresie wolności religijnej, zobowiązującą UKP do modyfikacji nazwy w taki sposób, aby jednoznacznie wskazywała na jego zależność od $\mathrm{RKP}^{14}$. W przypadku braku stosownej zmiany w statucie UKP w terminie czterech miesięcy od wejścia ustawy w życie oraz zmian w statutach jego wspólnot parafialnych - w terminie dziewięciu miesięcy, nowelizacja przewidywała utratę mocy prawnej tychże dokumentów w części mówiącej o pełnej nazwie organizacji religijnej. Art. 12 ustawy o wolności sumienia i organizacjach religijnych z 1991 r. uzupełniono o ust. 7 następującej treści: „Organizacja religijna (stowarzyszenie), która bezpośrednio bądź jako część innej organizacji religijnej (stowarzyszenia), wchodzi w skład (jest częścią) organizacji religijnej (stowarzyszenia), której ośrodek kierowniczy (zarząd) znajduje się poza granicami Ukrainy, w państwie, które zostało prawnie uznane za zaangażowane w agresję zbrojną przeciwko Ukrainie i/lub tymczasowo okupujące część terytorium Ukrainy, zobowiązana jest do odzwierciedlenia w swojej pełnej nazwie, zapisanej w swoim statucie, przynależności do organizacji religijnej (stowarzyszenia) poza granicami Ukrainy, w skład której wchodzi (jest częścią), poprzez obowiązkowe powielenie w swojej nazwie pełnej statutowej nazwy takiej organizacji religijnej (stowarzyszenia) $\mathrm{z}$ ewentualnym dodaniem

14 „Російська православна ичерква в Україні”: Рада зобов’язала УПЦ МП перейменуватись, https://www.bbc.com/ukrainian/news-46632682 [dostęp: 24.01.2021]. 
słów «na Ukrainie» i/lub określenia jej miejsca w strukturze zagranicznej organizacji religijnej ${ }^{15 "}$.

W ust. 8 art. 12 nowelizowanej ustawy o wolności sumienia i organizacjach religijnych znalazły się zapisy, że zastosowanie norm wyżej cytowanych zależne jest od wystąpienia jednej z przesłanek: 1) w statucie organizacji religijnej zapisano, że wchodzi ona w skład organizacji religijnej (stowarzyszenia), której ośrodek kierowniczy (zarząd) znajduje się poza granicami Ukrainy; 2) w statucie zagranicznej organizacji religijnej (stowarzyszenia), której ośrodek kierowniczy znajduje się w państwie uznanym za agresora, obecny jest zapis o wchodzeniu w jej skład organizacji religijnej działającej na Ukrainie, jak również prawo organów statutowych tejże zagranicznej organizacji religijnej (stowarzyszenia) do podejmowania decyzji w sprawach kanonicznych i organizacyjnych, które zobowiązywałyby do działań ukraińską organizację religijną; 3) w statucie zagranicznej organizacji religijnej (stowarzyszenia), której ośrodek kierowniczy znajduje się w państwie uznanym za agresora, przewidziany jest zapis o obowiązku wchodzenia w skład organów statutowych zagranicznej organizacji religijnej z prawem głosu kierownictwa ukraińskiej organizacji religijnej ${ }^{16}$.

W przepisach przejściowych i końcowych ustawy zapisano, że w ciągu miesiąca od wejścia w życie ustawy centralny organ władzy wykonawczej, który realizuje politykę państwa w sferze religii, czyli w ukraińskich warunkach Ministerstwo Kultury, przeprowadzi ekspertyzę religioznawczą statutów zarejestrowanych organizacji religijnych (lub stowarzyszeń) w celu ustalenia okoliczności przewidzianych w art. 12 ust. 7 i 8 ustawy nowelizowanej. W przypadku ustalenia powyższych okoliczności centralny organ władzy wykonawczej publicznie za pośrednictwem „Kuriera Rządowego" oraz bezpośrednio na piśmie poinformuje organizacje wyznaniowe i ich stowarzyszenia o konieczności dokonania stosownych

15 Закон України № 2662-VIII „Про внесення зміни до статті 12 Закону України 'Про свободу совісті та релігійні організаџії' щзодо назви релігійних організацій (об 'єднань), які входять до структури (є частиною) релігійної організації (об'єднання), керівний центр (управління) якої знаходиться за межами України в державі, яка законом визнана такою, щзо здійснила військову агресію проти України та/або тимчасово окупувала частину території Украӥни”, „Відомості Верховної Ради” 2019, № 3, ст. 23.

16 Tamże. 
zmian w statutach i ich przedłożenia do ponownej rejestracji w ciągu trzech miesięcy. Jeżeli takie zmiany nie zostaną wprowadzone w ciągu czterech miesięcy od momentu wejścia ustawy w życie, a w przypadku wspólnot parafialnych w ciągu dziewięciu miesięcy, wówczas statut organizacji religijnej traci moc obowiązującą w części dotyczącej jej nazwy. Organizacje religijne lub ich stowarzyszenia, których ośrodek kierowniczy znajduje się w państwie uznanym za agresora, prowadzą swoją działalność religijną bez przeszkód, z wyjątkiem ograniczenia dostępu duchowieństwa do jednostek Sił Zbrojnych Ukrainy i innych formacji wojskowych w miejscach ich dyslokacji ${ }^{17}$.

Za przyjęciem ustawy głosowało 240 posłów, przeciw 31, wstrzymał się 1 , spośród posłów biorących udział w posiedzeniu 17 nie głosowało ${ }^{18}$. Tego samego dnia dokument podpisał prezydent Petro Poroszenko, zaś ustawa weszła w życie 26 grudnia 2018 r.

Zgodnie z wynikami przeprowadzonej na podstawie przepisów końcowych i przejściowych ustawy ekspertyzy religioznawczej, zatwierdzonej nakazem nr 37 Ministra Kultury z dnia 25 stycznia 2019 r. w przypadku UKP zachodzą okoliczności, o których mowa w art. 12 ust. 7 i 8 nowelizowanej ustawy i powinien nosić nazwę „Ukraiński Kościół Prawosławny w jedności z Rosyjskim Kościołem Prawosławnym”. Ponadto w ekspertyzie wyróżniono także Rosyjski Kościół Prawdziwie Prawosławny, Rosyjski Kościół Staroobrzędowy (bezpopowcy), znany również jako Staroprawosławny Kościół Pomorski, Rosyjski Kościół Staroprawosławny (tzw. hierarchia nowozybkowska) oraz Rosyjski Prawosławny Kościół Staroobrzędowy. W ich przypadku stwierdzono, że nazwa oraz zapisy statutów odzwierciedlają podporządkowanie zagranicznym organizacjom lub

17 Tamże.

18 Поіменне голосування про проект Закону про внесення змін до Закону України „Про свободу совісті та релігійні організації” щзодо назви релігійних організацій (об 'єднань), які входять до структури (є частиною) релігійної організації (об'єднання), керівний иентр (управління) якої знаходиться за межами України в державі, яка законом визнана такою, щчо здійснила військову агресію проти Украйни та/або тимчасово окупувала частину території України (№ 5309) - за основу та в иілому, 20.12.2018 13:40, http://w1.c1.rada.gov.ua/pls/radan_gs09/ns_arh_golos?g_id=2144608\&n_skl=8 [dostęp: 24.01.2021]. 
stowarzyszeniom religijnym $\mathrm{z}$ siedzibą w państwie uznanym za agresora i nie muszą być zmieniane ${ }^{19}$.

Sprawą zmiany nazwy zajmowały się również ukraińskie sądy. Pod koniec kwietnia 2019 r. Okręgowy Sąd Administracyjny w Kijowie zawiesił proces zmiany nazwy przez UKP ${ }^{20}$. Z kolei w połowie grudnia 2019 r. Sąd Najwyższy zezwolił UKP na pozostanie przy nazwie dotychczasowej ${ }^{21}$. W odpowiedzi resort kultury 18 grudnia 2019 r. poinformował, że decyzji Sądu Najwyższego nie należy interpretować w ten sposób ${ }^{22}$. Warto dodać, że do chwili obecnej UKP nie zmienił nazwy, podważając konstytucyjność ustawy to nakazującej. Opozycyjni politycy 18 stycznia 2019 r. wnieśli do Sądu Konstytucyjnego wniosek o uchylenie ustawy.

Na początku lutego 2021 r. Święty Synod Kościoła Prawosławnego Ukrainy wydał oświadczenie w związku z rozpowszechnianymi w mediach informacjami o prawdopodobnym nielegalnym wpływie prorosyjskich polityków i zwolenników Patriarchatu Moskiewskiego na szereg orzeczeń sądowych, w którym potępił tego typu praktyki. Hierarchów KPU szczególnie zaniepokoiło ignorowanie przez ukraińską metropolię Patriarchatu Moskiewskiego zapisów ustawy z dnia 20 grudnia 2018 r.: „Będąc faktyczną częścią Rosyjskiego Kościoła Prawosławnego, jak wskazują dokumenty statutowe obu struktur [RKP oraz UKP - przyp. T.S.], co stanowi przesłankę zastosowania norm ustawy, stowarzyszenie religijne pod nazwą

19 Інформація Міністерства культури Украӥни - центрального органу виконавчої влади, щуо реалізує державну політику у сфері релігї стосовно переліку релігійних організацій (об'єднань), які підпадають під дію частин сьомої і восьмої статті 12 3акону Украӥни „Про свободу совісті та релігійні організації”, яким необхідно внести зміни до свого статуту (положення) та подати їх на реєстрацію у встановленому порядку, http://mincult.kmu.gov.ua/control/uk/publish/article?art_id=245450887 [dostęp: 24.01.2021].

20 Д. Горєвой, Що насправді відбувається з проиесом перейменування УПЦ (МП)?, https://risu.ua/shcho-naspravdi-vidbuvayetsya-z-procesom-pereymenuvannya-upc-mp_ n99354 [dostęp: 24.01.2021].

21 Верховний суд дозволив УПЦ Московського патріархату зберегти назву, https://www.rbc.ua/ukr/news/verhovnyy-sud-razreshil-upts-moskovskogo-1576513852. html [dostęp: 24.01.2021].

22 В Мінкультури заявили, що Верховний суд не дозволяв УПЦ МП залишити назву, https://www.rbc.ua/ukr/news/minkultury-zayavili-verhovnyy-sud-razreshal-1576666664. html [dostęp: 24.01.2021]. 
«Ukraiński Kościół Prawosławny» oraz zrzeszone w nim organizacje religijne, zasłaniając się orzeczeniami sędziów, którzy publicznie demonstrują swoją przynależność do Patriarchatu Moskiewskiego, już od dwóch lat nie respektuje wymogów ukraińskiego ustawodawstwa"'23. Konsekwencją takiego zaniechania ma być brak możliwości tworzenia nowych podmiotów kościelnych oraz brak możliwości zmian personalnych w strukturach UKP.

\section{ZMIANA PRZYNALEŻNOŚCI JURYSDYKCYJNEJ WSPÓLNOT PARAFIALNYCH}

Erygowanie nowego kościoła wzmogło proces przechodzenia parafii należących do UKP w jurysdykcję KPU. Aby uniemożliwić powstanie konfliktów na tym tle Rada Najwyższa na posiedzeniu 17 stycznia 2019 r. przyjęła ustawę nowelizującą przepisy prawne w zakresie wolności religijnej, precyzujące proces zmiany podległości parafii. Zgodnie z uzupełnionym art. 8 ustawy o wolności sumienia i organizacjach religijnych z 1991 r. podczas walnego zgromadzenia parafian mogą oni większością co najmniej 2/3 wszystkich członków wspólnoty (a nie tylko obecnych na spotkaniu) zdecydować o wyjściu ze struktury jednego kościoła i podporządkowaniu się w sprawach kanonicznych, organizacyjnych i jakichkolwiek innych drugiemu kościołowi. Stosowną zmianę należy wprowadzić do statutu i zarejestrować. Wówczas nie wpływa ona na prawa majątkowe parafii. Część wspólnoty, która nie zgadza się z decyzją o zmianie podporządkowania, ma prawo do utworzenia nowej parafii i zawarcia porozumienia w sprawie sposobu użytkowania świątyni i ruchomości z ich właścicielem (użytkownikiem). Powiadomienie organów państwowych o erygowaniu takiej wspólnoty nie jest obowiązkowe. $\mathrm{Z}$ kolei w art. 18 nowelizowanego aktu normatywnego znalazł się przepis zabraniający zmian majątkowych wspólnoty parafialnej do czasu zarejestrowania znowelizowanego statu-

23 Заява Свящеенного Синоду Української Православної Церкви (Православної Церкви України), https://www.pomisna.info/uk/vsi-novyny/zayava-svyashhennogo-synodu-ukrayinskoyi-pravoslavnoyi-tserkvy-pravoslavnoyi-tserkvy-ukrayiny/ [dostęp: 6.03.2021]. 
$\mathrm{tu}^{24}$. Przy niskiej frekwencji na sali posiedzeń, za zmianą ustawy głosowało 229 posłów, 35 przeciw, 2 wstrzymało się od głosu, zaś 40 zarejestrowanych do głosowania nie wzięło w nim udziału ${ }^{25}$. Prezydent P. Poroszenko podpisał ustawę 28 stycznia 2019 r., zaś dokument zaczął obowiązywać trzy dni później.

Ustawa z dnia 17 stycznia 2019 r. została zaskarżona do Sądu Konstytucyjnego przez 47 posłów z ramienia prorosyjskiego Bloku Opozycyjnego, zarzucających jej, że „niszczy wolność religijną oraz pokój międzywyznaniowy na Ukrainie, narusza konstytucyjne prawa i wolności obywateli, a zwłaszcza prawo do prowadzenia bez przeszkód działalności religijnej i stanowi bezpośrednie ingerowanie państwa w sprawy kościoła”, a także została przyjęta z naruszeniem parlamentarnych procedur (głosowanie przez nieupoważnione osoby) ${ }^{26}$. Niemniej dwa miesiące później, 19 marca 2019 r., po rozpatrzeniu przedmiotu sporu przez Wielką Izbę Sąd Konstytucyjny odmówił wszczęcia postępowania ${ }^{27}$.

Do końca marca 2021 r. 561 parafii prawosławnych na Ukrainie zmieniło jurysdykcję z UKP na KPU. Jako pierwsza 17 grudnia 2018 r. decyzję w tej sprawie podjęła wspólnota katedralnego Soboru Przemienienia Pańskiego w Winnicy. Jeszcze w ostatnich tygodniach 2018 r. podobne działania podjęło 35 wspólnot, niemniej intensyfikacja procesu nastąpiła w pierwszym kwartale 2019 r. - 482 parafii. Najwięcej parafii zmieniło

24 Закон України № 2673-VIII „Про внесення змін до деяких законів Украӥни щзодо підлеглості релігійних організацій та процедури державної реєстрації релігійних організацій зі статусом юридичної особи”, „Відомості Верховної Ради” 2019, № 6, ст. 40.

25 Поіменне голосування про проект Закону про внесення змін до деяких законів України (щодо підлеглості релігійних організацій та процедури державної реєстрачії релігійних організачій зі статусом юридичної особи) (№ 4128-д) - за основу та в цілому, 17.01.2019 11:26, http://w1.c1.rada.gov.ua/pls/radan_gs09/ns_arh_golos?g_ $\mathrm{id}=2163808 \&$ n_skl=8 [dostęp: 24.01 .2021$]$.

26 Ухвала Великої палати Конституиійного Суду України про відмову у відкритті конституційного провадження у справі за конституційним поданням 47 народних депутатів України щзодо відповідності Конституції України (конституційності) Закону України „Про внесення змін до деяких законів України щзодо підлеглості релігійних організаиій та процедури державної реєстрації релігійних організаиій зі статусом юридичної особи”, https://zakon.rada.gov.ua/laws/show/v011u710-19\#Text [dostęp: 24.01.2021].

${ }_{27}$ КС відмовив у оцінці закону про перехід релігійних громад у ПЦУ, https://www. pravda.com.ua/news/2019/03/20/7209743/ [dostęp: 24.01.2021]. 
przynależność w obwodach wołyńskim (124), winnickim (90) i chmielnickim (64), ale największy odsetek, mniej więcej co czwarta, w obwodach lwowskim i tarnopolskim. Od początku 2019 r. do sądów trafiła ponad setka wniosków ze strony struktur Patriarchatu Moskiewskiego dotyczących legalności zmiany przynależności konfesyjnej wspólnot z UKP na KPU.

Na posiedzeniu 24 lutego 2021 r. Sąd Najwyższy stwierdził, że stroną decyzji o zmianie przynależności jurysdykcyjnej parafii są jedynie członkowie wspólnoty i tylko oni mogą wnieść ewentualne odwołanie, a z prawa tego nie może skorzystać miejscowy ordynariusz. Taki punkt widzenia przyjęto na kanwie wyroku w sprawie 233/3516/18-ц, w której w lipcu 2018 r. metropolita gorłowski i słowiański UKP Mitrofan (Nikitin) złożył pozew o unieważnienie decyzji o zmianie przynależności parafii pw. Ofiarowania Pańskiego w Konstantynówce w obwodzie donieckim. Hierarcha Patriarchatu Moskiewskiego argumentował, że wszelkie decyzje parafian, w tym dotyczące zmian w obsadzie personalnej i przynależności kanonicznej, należy uzgodnić z miejscowym ordynariuszem, czego nie uczyniono. Sąd pierwszej instancji oraz sąd apelacyjny przyznały rację skarżącemu, niemniej Sąd Najwyższy uchylił ich orzeczenia ${ }^{28}$.

Inny, przełomowy wyrok w sprawie 910/10011/19, dotyczący zmiany przynależności parafii prawosławnej pw. Opieki Najświętszej Bogurodzicy w Sutkowcach w obwodzie chmielnickim, będącej właścicielem słynnej gotyckiej cerkwi obronnej, został wydany dnia 6 kwietnia 2021 r. przez Wielką Izbę Sądu Najwyższego. Pierwszy raz od początku procesu konwersji wspólnot prawosławnych w tego typu sprawie wypowiedział się Sąd Najwyższy, który potwierdził możliwość zmiany przynależności konfesyjnej parafii, uchylając orzeczenia Sądu Gospodarczego w Kijowie i sądu apelacyjnego. Sutkowiecka parafia zdecydowała o przejściu z UKP do KPU 23 lutego 2019 r., niemniej z decyzją większości nie chciał się pogodzić miejscowy proboszcz, który zaskarżył decyzję wspólnoty ${ }^{29}$.

28 Велика перемога ПЦУ над РПЦвУ - адвокат про рішення Верховного Суду, https://religionpravda.com.ua/?p=64795 [dostęp: 6.03.2021].

29 Верховний Суд ухвалив важливе рішення у питаннях зміни релігійними громадами свого підпорядкування, https://www.pomisna.info/uk/vsi-novyny/verhovnyj-sud-uhvalyvvazhlyve-rishennya-u-pytannyah-zminy-religijnymy-gromadamy-svogo-pidporyadkuvannya/ [dostęp: 15.04.2021]. 
6. OGRANICZENIA W DOSTĘPIE DO OPIEKI DUSZPASTERSKIEJ W SIŁACH ZBROJNYCH I INNYCH FORMACJACH WOJSKOWYCH

W obowiązującej od przeszło trzech dekad ustawie o wolności sumienia i organizacjach religijnych kwestii opieki duszpasterskiej w Siłach Zbrojnych i innych formacjach wojskowych dotyczy w części art. 21, stanowiący, że dowódcy jednostek wojskowych umożliwiają żołnierzom udział w nabożeństwach i wykonywanie obrzędów religijnych. Kilkukrotnie podejmowano próby uchwalenia przez Radę Najwyższą ustawy regulującej zagadnienie duszpasterstwa wojskowego, ale procedowane na forum parlamentu projekty nie uzyskały poparcia większości posłów ${ }^{30}$.

Pomimo braku wyraźnych podstaw normatywnych jako pierwsze instytucję kapelanów wprowadziły Wojska Wewnętrzne już latem 1999 r., natomiast w Siłach Zbrojnych proces ten zaczął się wiosną 2006 r. $^{31}$ W obliczu wojny na wschodzie Ukrainy interesującą nas problematykę uregulowano w rozporządzeniu Gabinetu Ministrów Ukrainy z dnia 2 lipca 2014 r. „O służbie duchowieństwa wojskowego (służbie kapelańskiej) w Siłach Zbrojnych, Gwardii Narodowej oraz Państwowej Służbie Granicznej" "32. Zobowiązano w nim Ministerstwo Obrony, Ministerstwo Spraw Wewnętrznych oraz Administrację Państwowej Służby Granicznej, aby w ciągu miesiąca opracowali i przyjęli stosowne statuty dotyczące służby kapelańskiej, uwzględniające, że duchowni, którzy zostaną wskazani przez organizacje religijne oraz pomyślnie przejdą selekcję, podpiszą umowy o pracę z Siłami Zbrojnymi, Gwardią Narodową bądź Państwową Służbą Graniczną, tym samym stając się częścią personelu tychże struktur i otrzymując status duchownego wojskowego (kapelana).

30 Рог. Постанова Верховної Ради України ,Про прийняття за основу проекту Закону Украӥни про військове Капеланство”, „Відомості Верховної Ради” 2019, № 27, ст. 114.

31 Директива від 21 квітня 2006 року № Д-25 „Про впорядкування питань задоволення релігійних потреб військовослужбовців Збройних Сил Украӥни”, https://www. kapelanstvo.ugcc.ua/dyrektyva-d-25-pro-vporyadkuvannya-pyta/ [dostęp: 24.01.2021].

32 Розпорядження від 2 липня 2014 р. N 677-p „Про службу військового духовенства (капеланську службу) у Збройних Силах, Національній гвардії та Державній прикордонній службі", https://zakon.rada.gov.ua/laws/show/677-2014-\%D1\%80\#Text [dostęp: 24.01.2021]. 
W ciągu kolejnego miesiąca miano dokonać wyboru kandydatów na stanowiska kapelanów. Ministerstwo Polityki Społecznej zostało zobowiązane do uwzględnienia kapelanów wojskowych w klasyfikacji zawodów. Tak też się stało i zawód „duchowny wojskowy (kapelan)” pojawił się w 2016 r. w klasyfikacji zawodów w rozdziale II „Specjaliści” Ministerstwa Obrony pod numerem 2125, a pod numerem 2460 w ogólnej klasyfikacji33.

Na przełomie XX i XXI w. w ramach centralnych struktur kościelnych zaczynają powstawać komórki odpowiedzialne za duszpasterstwo wojskowe. Jeszcze w lipcu 1999 r. przy metropolicie kijowsko-halickim UKP powstał Synodalny Wydział ds. współpracy z Siłami Zbrojnymi i innymi formacjami wojskowymi z ordynariuszem lwowsko-halickim Augustynem (Markiewyczem) na czele. Warto dodać, że metropolita Augustyn był odpowiedzialny za kontakty z resortami obrony i spraw wewnętrznych oraz formacjami wojskowymi od grudnia 1996 r. W marcu 2002 r. UKP przyjął dokument pt. „Podstawowe aspekty koncepcji opieki duszpasterskiej w Siłach Zbrojnych i innych ukraińskich formacjach wojskowych"34.

Jednym $\mathrm{z}$ elementów reformy ukraińskiego systemu bezpieczeństwa narodowego po rewolucji godności było odnowienie Gwardii Narodowej Ukrainy, powstałej na bazie Wojsk Wewnętrznych, rozformowanych wiosną 2014 r. ${ }^{35}$ W kwietniu 2016 r. Minister Spraw Wewnętrznych Arsen Awakow zatwierdził Statut służby duszpasterstwa wojskowego (służby kapelańskiej) w Gwardii Narodowej Ukrainy z dnia 24 marca 2016 r. W kontekście tematu niniejszego artykułu warto zaznaczyć, że w rozdziale IV „Duszpasterze wojskowi (kapelani)”, w p. 19 zapisano, że dowództwa jednostek wojskowych, „nie dopuszczają (ograniczają działalność)

33 Наказ Міністра оборони України від 19 жовтня 2016 р. № 543 „,Про затвердження Переліку професійних назв робіт працівників Збройних Сил України та Переліку облікових спеціальностей працівників Збройних Сил України”, https://zakon.rada.gov.ua/ laws/show/z1456-16 [dostęp: 24.01.2021].

34 Основні аспекти Концепиії душпастирської опіки у Збройних Силах та інших військових формуваннях Украӥни, http://archiv.orthodox.org.ua/page-1671.html [dostęp: 24.01.2021].

35 Szyszlak 2018, 35. 
duszpasterzy tych organizacji religijnych, których ośrodki kierownicze znajdują się na terytorium państw agresorów"36.

Podobnego zapisu nie odnajdziemy w Statucie służby duszpasterstwa wojskowego (służby kapelańskiej) w Siłach Zbrojnych Ukrainy z dnia 14 grudnia 2016 r., niemniej dokument ten przewiduje konieczność uzyskania przez kandydata na stanowisko duszpasterza wojskowego pozytywnej opinii ze strony Służby Bezpieczeństwa Ukrainy (rozdział IV, pkt 5) ${ }^{37}$. Być może fakt ten jest przyczyną, że wśród 90 osób zatrudnionych jako kapelani w jednostkach wojskowych - zgodnie z danymi Sztabu Generalnego Sił Zbrojnych Ukrainy z 28 września 2020 r. - znalazł się tylko jeden z UKP, podczas gdy KPU reprezentowało 59 duchownych, 20 UKG, zaś 10 wspólnoty protestanckie ${ }^{38}$.

Swego czasu zastępca przewodniczącego Wydziału ds. współpracy z Siłami Zbrojnymi i innymi formacjami wojskowymi UKP, archimandryta Luka (Winarczuk), informował o przypadkach, kiedy ze Sztabu Generalnego telefonicznie udzielano wskazówek, aby we wnioskach z jednostek wojskowych o zatrudnienie duchownych UKP w charakterze kapelanów wojskowych dokonywać korekty i podawać przedstawicieli innych konfesji ${ }^{39}$. Archimandryta twierdził również, że istnieje specjalna dyrektywa Sztabu Generalnego, która zakazywałaby dopuszczania duchownych UKP do jednostek wojskowych, co też w odpowiedzi Ministerstwo Obrony Ukrainy zdementowało ${ }^{40}$.

36 Наказ № 205 „Про затвердження Положення про службу військового духовенства (капеланську службу) у Національній гвардії України”, „Офіційний вісник України” 2016, № 39, ст. 1496.

37 Наказ № 685 ,Про затвердження Положення про службу військового духовенства (капеланську службу) у Збройних Силах Украӥни”, „Офіційний вісник України” 2017, № 7, ст. 206.

38 Капелани в ЗСУ: скільки їх, яких цеерков, скільки заробляють, https://novynarnia.com/2020/10/06/kapelany-v-zsu/ [dostęp: 24.01.2021].

39 Виявлено факти дискримінаиії православних військовослужбовиів, https://news. church.ua/2017/04/11/viyavleno-fakti-diskriminaciji-pravoslavnix-vijskovosluzhbovciv/[dostęp: 24.01.2021].

40 Роз'яснення щзодо Положення про службу військового духовенства (капеланську службу) у Збройних Силах України, https:/www.mil.gov.ua/dlya-zmi/reaguvannya-na-kritiku/2018/11/09/rozyasnennya-shhodo-polozhennya-pro-sluzhbu-vijskovogo-duhovenstva-(kapelansku-sluzhbu)-u-zbrojnih-silah-ukraini/ [dostęp: 24.01.2021]. 


\section{PODSUMOWANIE}

Regulacje przyjęte w latach 2014-2019 w stosunku do UKP mają charakter dyskryminacyjny. Zostały one przyjęte w wyniku procesu sekurytyzacji największej pod względem liczby parafii i drugiej pod względem identyfikacji konfesyjnej wspólnoty kościelnej na Ukrainie - UKP. W wyniku klasycznego procesu sekurytyzacji, konstruowania zagrożenia i powielanego aktu mowy Rada Najwyższa, ale również podmioty władzy wykonawczej wydały akty normatywne jawnie dyskryminujące UKP poprzez nakaz zmiany nazwy czy niedopuszczanie kapelanów do pracy duszpasterskiej w jednostkach wojskowych. Co znaczące, nowe władze, które u sterów rządów znalazły się po 2018 r., nie zmieniły przyjętych przez poprzedników restrykcyjnych zapisów. Pozytywnie zweryfikowano zatem postawioną w pierwszych akapitach artykułu hipotezę badawczą.

\section{BIBLIOGRAFIA}

Fijałkowski, Łukasz. 2012. „Teoria sekurytyzacji i konstruowanie bezpieczeństwa". Przeglad Strategiczny 1: 149-162.

Hofreiter, Ladislav. 2012. Wstęp do studiów bezpieczeństwa. Kraków: Krakowska Akademia im. Andrzeja Frycza Modrzewskiego.

Kozyrska, Antonina. 2014. Pluralizm wyznaniowy a integracja narodu ukraińskiego po 1991 roku. Toruń-Łysomice: Europejskie Centrum Edukacyjne.

Misztal, Henryk. 2003. „Systemy relacji państwo-Kościół”. W: Prawo wyznaniowe, red. Henryk Misztal, Piotr Stanisz, 36-58. Lublin: Wydawnictwo KUL.

Strutyński, Maciej. 2014. „Stosunki między państwem a związkami wyznaniowymi w niepodległej Ukrainie (1991-2013)". Studia z Prawa Wyznaniowego 17: 255-273.

Szyszlak, Elżbieta. 2015. „Sekurytyzacja problematyki mniejszości narodowych i etnicznych w Europie Środkowo-Wschodniej”. W: Polityka etniczna: teorie, koncepcje, wyzwania, red. Henryk Chałupczak, Radosław Zenderowski, Ewa Pogorzała, Tomasz Browarek, 103-117. Lublin: Wydawnictwo Uniwersytetu Marii Curie-Skłodowskiej.

Szyszlak, Tomasz J. 2007. „Wolność religijna w konstytucjach i ustawach wyznaniowych państw postradzieckich". Studia z Prawa Wyznaniowego 10: 225-260. 
Szyszlak, Tomasz. 2012. Lwowskie sacrum, kijowskie profanum. Grekokatolicyzm w ukraińskiej przestrzeni publicznej od pierestrojki do pomarańczowej rewolucji. Warszawa: Polskie Towarzystwo Religioznawcze.

Szyszlak, Tomasz. 2018. „Przekształcenia w ukraińskim systemie bezpieczeństwa narodowego po rewolucji godności. Wybrane aspekty". Wschodnioznawstwo 12: 27-44.

Szyszlak, Tomasz. 2020. „The conflict over the autocephaly of Ukrainian Orthodoxy as an element of the hybrid war". Rocznik Instytutu Europy Środkowo-Wschodniej 3: 49-71.

Wróblewski, Ryszard. 2017. Wstęp do nauk o bezpieczeństwie. Siedlce: Wydawnictwo Uniwersytetu Przyrodniczo-Humanistycznego. 